\title{
Development of culinary recipes in an intervention program with Brazilian university students
}

\section{Desenvolvimento de receitas culinárias em}

\section{programa de intervenção com}

\section{universitários brasileiros}

\author{
Halana Ataíde Köche RITA ${ }^{1}$ iD 0000-0001-7496-8119 \\ Greyce Luci BERNARDO1 (iD) 0000-0003-0411-012X \\ Manuela Mika JOMORI ${ }^{1}$ iD 0000-0003-2294-6692 \\ Ana Carolina FERNANDES ${ }^{1}$ (D) 0000-0002-8179-4855 \\ Rossana Pacheco da Costa PROENÇA ${ }^{1}$ (D) 0000-0001-6149-8752
}

\section{A B S T R A C T}

\section{Objective}

Develop and test recipes for a cooking skills intervention program aimed at students of a Brazilian university.

\section{Methods}

Culinary recipes were selected for the Nutrition and Culinary in the Kitchen program, which offers cooking classes for participants to practice and develop their cooking skills. The Nutrition and Culinary in the Kitchen program is based on the Cooking with a Chef program of the United States of America. A literature search was conducted to establish criteria for the selection and development of recipes. A decision tree was constructed to determine if Cooking With a Chef recipes were appropriate for the Nutrition and Culinary in the Kitchen program. Recipes were evaluated in the laboratory by untrained university students using an acceptance test that comprised the analysis of sensorial attributes and healthiness criteria.

1 Universidade Federal de Santa Catarina, Centro de Ciências da Saúde, Programa de Pós-Graduação em Nutrição, Núcleo de Pesquisas de Nutrição em Produção de Refeições. Campus Reitor João David Ferreira Lima, s/n., Trindade, 88040-900, Florianópolis, SC, Brasil. Correspondência para/Correspondence to: RPC PROENÇA. E-mail: <rossana.costa@ufsc.br>

Como citar este artigo/How to cite this article

Rita HAK, Bernardo GL, Jomori MM, Fernandes AC, Proença RPC. Development of culinary recipes in an intervention program with Brazilian university students. Rev Nutr. 2018;31(4):397-411. http://dx.doi.org/10.1590/1678-98652018000400005 


\section{Results}

Of the 32 developed recipes, nine were based on the Cooking With a Chef program. Recipes were adapted to increase the use of fresh fruits, whole grains, and vegetables; eliminate ultra-processed foods; and take into account local food habits and seasonality of ingredients. In the first test, $53.3 \%(n=16)$ of the dishes received an acceptance score of less than $70.0 \%$ mainly because of unsatisfactory taste. Culinary recipes considered inadequate were redesigned in terms of ingredients and/or cooking methods and were retested until achieving a score of $100.0 \%$.

\section{Conclusion}

Culinary recipes adapted to the Brazilian food culture and the target audience with the use of healthy ingredients and cooking techniques were considered appropriate for the Nutrition and Culinary in the Kitchen cooking skills intervention program and might increase participants' adherence to healthy eating habits.

Keywords: College students. Culinary education. Food preparation. Healthy diet. Intervention.

\section{RES U M O}

\section{Objetivo}

Esta pesquisa teve como objetivo desenvolver e testar receitas culinárias para serem aplicadas em programa de intervenção sobre habilidades culinárias, com estudantes universitários brasileiros.

\section{Métodos}

Selecionaram-se receitas culinárias para o Programa de Intervenção Nutrição e Culinária na Cozinha, que objetiva realizar oficinas culinárias e praticar habilidades culinárias, com base no programa estadunidense Cooking With a Chef. Foi realizada busca na literatura para definição de critérios para seleção e desenvolvimento das receitas culinárias. Elaborou-se árvore decisória para verificar a possibilidade de utilizar as receitas do programa norteamericano. As receitas culinárias foram testadas em laboratório por estudantes universitários não treinados, quando foi feito o teste de aceitação adaptado incluindo atributos sensoriais e de critérios para considerar uma receita culinária saudável.

\section{Resultados}

Das 32 preparações selecionadas, adaptadas e testadas, nove eram originais do programa Cooking With a Chef. As principais adaptações foram o uso de frutas in natura, cereais integrais e leguminosas, bem como a eliminação de alimentos ultraprocessados e a adequação aos hábitos alimentares locais e à sazonalidade dos ingredientes. No primeiro teste, 53,3\% $(n=16)$ das preparações culinárias obtiveram percentual de adequação abaixo de 70,0\%, principalmente devido ao sabor. As preparações consideradas inadequadas tiveram alterações nos ingredientes ou no modo de preparo, sendo testadas até atingirem 100,0\% de adequação.

\section{Conclusão}

As receitas culinárias adaptadas de acordo com a cultura brasileira e o público-alvo, inserindo-se ingredientes e técnicas de preparo mais saudáveis, foram consideradas adequadas ao programa proposto e podem contribuir para a adesão ao programa de intervenções que visa o desenvolvimento de hábitos alimentares mais saudáveis.

Palavras-chave: Universitários. Educação culinária. Preparações culinárias. Dieta saudável. Intervenção.

\section{NTRODUCTION}

The period between adolescence and adulthood - the age range of most university students - is considered a moment of transition. During this phase, young people develop autonomy from parents and acquire new health behaviors [1]. Some studies indicate that the first semester at university can be a period of weight gain and increased body fat for this population [2-4].

Studies show that students' eating habits are influenced by the educational environment and surrounding communities. Most university students report a high consumption of processed foods, such as sweets, cakes, pies, fast foods, and soft drinks, and a low consumption of fruits, vegetables, legumes, and whole grains [5-8]. 
The Guia Alimentar para a População Brasileira (GAPB, Dietary Guidelines for the Brazilian Population), since its first edition, provides dietary recommendations for healthy food choices [9]. The most recent GAPB edition specifically highlights the importance of developing, exercising, and sharing cooking skills to sustain healthy eating behaviors [10].

Cooking skills can be defined as "confidence, attitude, and application of individual knowledge to perform cooking tasks that range from planning menus and shopping to food preparation, whether involving the use of unprocessed, minimally processed, processed, or ultra-processed ingredients". Note that this definition considers food-related aspects as well as aspects related to the individual. The "food aspect" of the definition refers to foods submitted to different cooking techniques, considering the need to prepare dishes from scratch, whereas the "individual-focused aspects" involves personal characteristics such as confidence, attitude, intention, and knowledge about cooking [11]. The development of cooking skills can promote healthy eating practices by stimulating the use of natural ingredients and discouraging the use and consumption of ultra-processed foods.

Studies have discussed the relationship between cooking skills and healthy eating $[12,13]$. Some studies indicate an association between cooking skills, frequent consumption of fruits and vegetables, and low consumption of convenience foods [12-14]. In addition, international intervention programs demonstrated that the promotion of cooking skills has a positive effect on eating behaviors [14-17].

Cooking skills intervention studies can include the development of culinary recipes. Recipes should be healthy, tailored to the target audience, and should provide an opportunity for participants to learn basic nutrition and cooking principles. Therefore, it is important that recipes be tested beforehand and that testers are equipped with the technical knowledge and skills to provide relevant information for revising recipes [18].

The aim of this study was to select, adapt, and test culinary recipes for a cooking skills intervention aimed at students of a university in southern Brazil.

\section{METHO D S}

In this cross-sectional [19] exploratory [20] study, culinary recipes were developed for the Brazilian Nutrition and Culinary in the Kitchen (NCK) intervention program [21]. The NCK is based on the Cooking With a Chef (CWC) intervention program of the University of Clemson, South Carolina, United States of America (USA) [15,22,23].

The decision to choose CWC as a reference for the NCK program was based on the results of a systematic literature review conducted in 2016 [22] and updated in 2017. Cooking With a Chef was the only hands-on cooking skills intervention program retrieved from the literature search that discussed topics in the field of Nutrition and Culinary Sciences with the aim of assessing and developing participants' cooking skills. Cooking With a Chef uses a validated tool to evaluate different cooking skill dimensions, such as cooking attitudes, knowledge, and self-efficacy, and behaviors related to the preparation and consumption of fruits and vegetables. This assessment tool has been applied in different contexts in the USA, including a university setting $[15,24]$, and has been cross-culturally adapted and validated in Brazil [25]. The CWC program adopts a theoretical approach based on Social Cognitive Theory, considering the relationship between individuals, behaviors, and the environment. This approach broadens the scope of the program, as it goes beyond individual issues of changes in behavior and assesses the relationships and influences of the environment on individuals [22]. The present study depicts one of the steps in the adaptation of the US CWC program to 
the Brazilian NCK program, the development of culinary recipes.

The NCK program is structured into five hands-on cooking classes and a food selection and purchase workshop in a budget-friendly market [22], without any theory sessions. The program's goals are to provide knowledge on nutrition and cooking principles, encourage the preparation and consumption of fruits and vegetables, and provide an opportunity for participants to develop their cooking skills and feel at ease and confident in preparing healthy meals. As an additional benefit, the NCK program might also stimulate the adoption of healthier food choices in meals eaten out of home [21].

We highlight that culinary recipes were chosen and adapted in consonance with the aims of the CWC program. We also highlight the difficulty in finding scientific information on the adaptation of culinary recipes for intervention programs.

To systematize the process of recipe development, we considered the following guiding principles: number and aim of hands-on cooking classes to be administered; number of recipes to be taught in each class; characteristics of the target audience (age, gender, and education level); average time to prepare recipes, with a preference for recipes with feasible preparation times; cooking utensils and ingredients required; average cost of each dish; and cooking techniques to be taught in each class [21,22]. A literature review was carried out to identify public policies and national and international government recommendations on the promotion of healthy eating $[9,10,26-29]$.

On the basis of the literature review, the following criteria were adopted to classify a culinary recipe as healthy: preference for unprocessed and minimally processed foods, limited use of salt and sugar, use of herbs and spices for seasoning, use of healthy cooking techniques (for instance, roasting, sautéing, and steaming), use of vegetables according to seasonality, preference for organic and family farm foods, elimination of ultra-processed foods, and elimination of ingredients with industrial trans fatty acids $[9,10,27-29]$. The time of preparation, difficulty level, and cost of ingredients were also taken into consideration, as these factors were reported by university students as the main obstacles to healthy eating [8].

A decision tree (Figure 1) was constructed to select culinary recipes and define whether the original CWC recipes required adaptations before being tested. Brazilian cookbooks and cooking websites were used as a reference to adapt or search for new culinary recipes.

After having defined the culinary recipes for the NCK classes, a shopping list was elaborated specifying the ingredients and quantities necessary for preparing five portions of each recipe. Portion sizes were presented in common household measures, as recommended by the GAPB [9], and the term used to refer to each ingredient was standardized according to the Tabela Brasileira de Composição de Alimentos (TACO, Brazilian Food Composition Table) [30].

Regarding salt content, we adopted the recommendation [31] of limiting salt to up to $1 \%$ of the net weight of food, prioritizing the use of herbs, condiments, and spices to add flavor to dishes. A qualitative analysis was performed to investigate the presence of ultra-processed ingredients in the original CWC recipes and in the recipes developed for the NCK program. The original recipes included many ultra-processed ingredients; therefore, it can be concluded that the adapted recipes, created by substituting ultra-processed ingredients with unprocessed ingredients, had a qualitative reduction in sodium, sugar, and trans fat contents. This affirmation is supported by studies that show that ultra-processed foods are rich in sodium, sugars, and trans fats [27,31-34].

All recipes were tested and analyzed in a university lab kitchen from March to April 2016. 


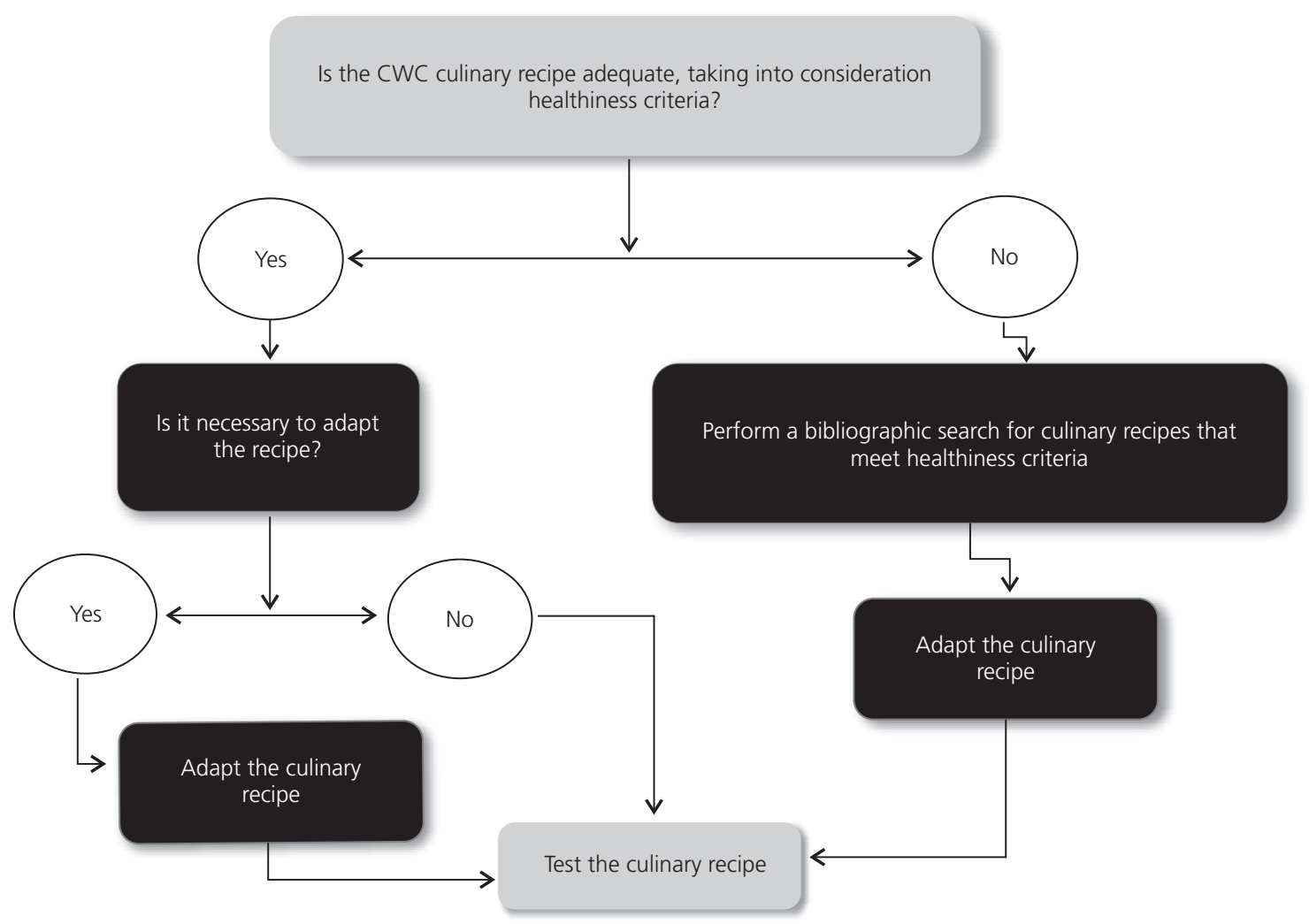

Figure 1. Decision tree for the selection of culinary recipes to be tested and used in a culinary intervention program for Brazilian university students.

An adapted version of the acceptance test, known as adequacy test, was used to evaluate the acceptance of the culinary recipes. The standardized questionnaire included an affective scale of specific sensory attributes, such as appearance, color, smell, texture, and taste [35], which could be labeled either as "adequate" or "inadequate," and a list of the healthiness criteria previously described, with two possible answers, "yes" or "no". Recipes had to reach a score above $70 \%$ [31] for sensorial attributes and a score of $100 \%$ for healthiness to be considered suitable to be used in the NCK cooking classes. Recipes were initially tested on three different days; recipes that did not achieve the required sensorial score were retested once after adaptation.

Most culinary recipes were evaluated by five untrained tasters, which included undergraduate and graduate students in nutrition. In addition, two academic experts participated in the tasting sessions: a researcher with a technical degree in cooking who was trained by the US CWC program and a researcher with previous teaching experiences in cooking techniques. Some recipes were evaluated by three or four tasters.

A bibliographic analysis was carried out to standardize the information presented in culinary recipes with respect to the target audience, list of kitchen utensils, ingredients and possible substitutions, preparation time, household measures, cooking techniques, and ease of comprehension [21]. A methodology adapted from a consensus workshop [36] was used to assess the clarity of the information. The expert committee consisted of three nutritionists 
and a nutrition student. Culinary recipes were analyzed and reviewed by the authors of the study until consensus was reached regarding clarity. This study was approved by the Human Research Ethics Committee of the proponent university (project $n^{\circ} 1.318 .443$ ). A descriptive analysis of adequacy test scores was carried out by means relative frequencies. Statistical analysis was carried out using Microsoft Office Excel ${ }^{\circledR}$ (Microsoft Corp., Redemond, Washington DC, United States).

\section{RE S U L T S}

Of the 24 CWC recipes, 15 were excluded for not meeting the healthiness criteria and/or for not being adaptable to the Brazilian culture. Subsequently, following the considerations of the CWC program with respect to the goals of each class, 32 culinary recipes were developed and adapted to the NCK program: nine adapted from the CWC recipes and 23 developed and adapted from cookbooks and cooking websites. The reasons for the modifications are presented in Chart 1.

Cooking With a Chef recipes were adapted mainly to include ingredients better suited to the Brazilian food culture while considering the seasonality of fruits and vegetables and the seasons in which the cooking classes were to be held; to increase the use of whole grains, legumes, and fruits; and to include homemade sauces and gravies. Alterations also included substitution of processed foods such as canned tomatoes, canned beans, and canned meat for unprocessed foods. Fresh foods and traditional versions of a product were preferred over diet/light products, which are generally ultraprocessed and have the addition of synthetic ingredients [10].

Recipes from cookbooks and websites were modified mainly because of seasonality aspects, to reduce the amounts of salt and sugar, and to replace ultra-processed seasonings with fresh or dehydrated herbs and spices.

All culinary recipes were tested and, with the exception of homemade chicken and vegetable broths, all recipes were submitted to the adequacy test of sensorial attributes, as presented in Table 1.

Recipes that received a sensory score of less than $70.0 \%(n=16)$ were redesigned, retested, or had their ingredients changed. Of the total number of inadequate recipes, 10 $(41.7 \%)$ were due to taste, five $(20.8 \%)$ were due to visual aspects, five (20.8\%) were due to texture, three $(12.5 \%)$ to color, and one $(4.2 \%)$ to smell. The main reason for a low score in the sensory test was poor taste.

Seven recipes were re-evaluated by five untrained tasters. Chart 2 presents the seven recipes, the modifications, and the reasons for the modifications. After being redesigned, all culinary recipes received a score of $100 \%$ in all sensory attributes.

The other recipes with low sensory scores $(n=9)$ were not retested, as they only required small adjustments in the amount of ingredients or preparation method. This decision was made unanimously by the researchers involved in the study. For instance, the taste attribute of roasted vegetables received a score of $20 \%$ because of an excess of pepper; thus, to adjust the recipe, we simply reduced the amount of pepper. Mint leaves and papaya were added to the fruit salad to improve the color attribute, which had received a score of $40 \%$. Beef steak with onions received a low score because of an inappropriate cut of meat chosen at the time of purchase, which caused the muscle fibers to contract during cooking, consequently compromising texture and appearance. To solve this problem, an appropriate cut of meat was required at the purchase moment.

After defining the recipes for the NCK cooking classes, we elaborated a culinary recipe model (Figure 2). 
Chart 1. Culinary recipes of the Cooking with a Chef (CWC) program, culinary recipes of the Brazilian Nutrition and Culinary in the Kitchen (NCK) program, and main reasons for adapting the recipes aligned with the NCK class goals. Santa Catarina (SC), Brazil, 2016.

\begin{tabular}{|c|c|c|c|}
\hline & CWC menu* & Menu adapted for the NCK program & Reasons for adapting recipes \\
\hline \multirow{6}{*}{ 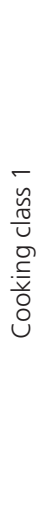 } & Vegetable soup & Roasted vegetables & $\begin{array}{l}\text { Prepare recipes according to the season (e.g., } \\
\text { hot soups were replaced with cold salads for } \\
\text { the summer). }\end{array}$ \\
\hline & $\begin{array}{l}\text { Fruit salad with yogurt and } \\
\text { granola }\end{array}$ & Fresh fruit salad & $\begin{array}{l}\text { Encourage the use of fresh fruits without adding } \\
\text { other ingredients to facilitate consumption. }\end{array}$ \\
\hline & $\begin{array}{l}\text { Sautéed, roasted, and poached } \\
\text { chicken (demonstration) }\end{array}$ & Omelet & Encourage the use of homemade broths. \\
\hline & & $\begin{array}{l}\text { Sautéed, baked, and pressure cooker } \\
\text { chicken (demonstration) }\end{array}$ & $\begin{array}{l}\text { Substitute poaching with pressure cooking to } \\
\text { enhance sensorial characteristics and optimize } \\
\text { cooking time. }\end{array}$ \\
\hline & & Homemade vegetable broth & Encourage the use of egg-based recipes. \\
\hline & & Homemade chicken broth & \\
\hline \multirow{4}{*}{ 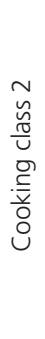 } & Sweet and sour chicken salad & Chicken salad & Adapt ingredients to the Brazilian food culture. \\
\hline & Tomato sauce with peaches & Yogurt sauce & $\begin{array}{l}\text { Encourage the preparation of fresh fruits } \\
\text { using different preparation techniques } \\
\text { without adding other ingredients to facilitate } \\
\text { consumption. }\end{array}$ \\
\hline & Creamy fruit salad & Fresh fruit cream sherbet & Encourage the use of whole grains. \\
\hline & & Whole wheat frying pan bread & $\begin{array}{l}\text { Encourage the use of homemade salad } \\
\text { dressing. }\end{array}$ \\
\hline \multirow{6}{*}{ 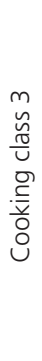 } & Roasted meatballs & Whole grain rice with garlic & $\begin{array}{l}\text { Encourage the preparation of a typical Brazilian } \\
\text { meal. }\end{array}$ \\
\hline & Baked sweet potato & Black beans cooked with pumpkin & Adapt ingredients to the Brazilian food culture. \\
\hline & Coleslaw & Beef steak with onions & Encourage the use of homemade salad dressing. \\
\hline & $\begin{array}{l}\text { Creamy fruit salad with poppy } \\
\text { seeds }\end{array}$ & Mixed salad & $\begin{array}{l}\text { Encourage the use of fresh fruits without adding } \\
\text { other ingredients to facilitate consumption. }\end{array}$ \\
\hline & Barbecue sauce & Vinaigrette dressing & \\
\hline & Black-eyed pea hummus & Orange & \\
\hline \multirow{7}{*}{ 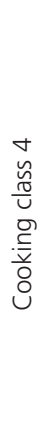 } & Corn and white bean soup & Roasted meatballs & Adapt ingredients to the Brazilian food culture. \\
\hline & Broccoli salad with chickpeas & Whole wheat pasta & Prepare recipes according to the season. \\
\hline & Banana pudding & Homemade tomato sauce & $\begin{array}{l}\text { Encourage the use of fresh fruits without adding } \\
\text { other ingredients to facilitate consumption. }\end{array}$ \\
\hline & Whole grain rice & $\begin{array}{l}\text { Broccoli salad with lentils and cashew } \\
\text { nuts }\end{array}$ & $\begin{array}{l}\text { Encourage the use of whole grains, legumes, } \\
\text { nuts, and seeds. }\end{array}$ \\
\hline & Whole wheat pasta & Salad dressing & Encourage the use of homemade salad dressing. \\
\hline & & Fresh fruit platter & Encourage the use of homemade tomato sauce. \\
\hline & & Seasoned salt (demonstration) & $\begin{array}{l}\text { Encourage the use of seasoned salt to lower } \\
\text { sodium intake. }\end{array}$ \\
\hline \multirow{4}{*}{ 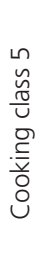 } & Sautéed chicken & $\begin{array}{l}\text { Stewed fish with coconut milk } \\
\text { (Moqueca) }\end{array}$ & $\begin{array}{l}\text { Adapt ingredients and dish to the Brazilian food } \\
\text { culture. } \\
\text { Encourage the use and intake of fish. }\end{array}$ \\
\hline & Whole wheat pasta & Parboiled rice with parsley & \\
\hline & & Fish Pirão & $\begin{array}{l}\text { Adapt ingreaients and dish to the Brazilian rood } \\
\text { culture. }\end{array}$ \\
\hline & & Farofa & \\
\hline
\end{tabular}


Chart 1. Culinary recipes of the Cooking with a Chef (CWC) program, culinary recipes of the Brazilian Nutrition and Culinary in the Kitchen (NCK) program, and main reasons for adapting the recipes aligned with the NCK class goals. Santa Catarina (SC), Brazil, 2016.

\begin{tabular}{|c|c|c|c|}
\hline & CWC menu* & Menu adapted for the NCK program & Reasons for adapting recipes \\
\hline \multirow{3}{*}{ 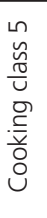 } & Salad with lettuces and chick peas & $\begin{array}{l}\text { White bean salad with onions, lettuce } \\
\text { and tomatoes }\end{array}$ & $\begin{array}{l}\text { - Encourage the use of whole grains, legumes, } \\
\text { nuts, and seeds. }\end{array}$ \\
\hline & $\begin{array}{l}\text { Marinara Sauce with tomatoes } \\
\text { and mushrooms }\end{array}$ & $\begin{array}{l}\text { Orange, mustard and honey salad } \\
\text { dressing }\end{array}$ & $\begin{array}{l}\text { - Encourage the use of homemade salad } \\
\text { dressing. }\end{array}$ \\
\hline & Pineapple Cake & Whole-meal cake & - Encourage the use of fresh fruits in the cakes. \\
\hline
\end{tabular}

Note: Based on $[15,21,22,24]$

An appropriate writing style was used taking into consideration the target audience. Recipes were reviewed for readability, clarity, and usability.

\section{DISCUSSION}

Considering the objectives of the present study, we adapted nine recipes from the CWC program. The other culinary recipes $(\mathrm{N}=23)$ were developed and adapted from cookbooks and websites. In total, 32 culinary recipes were developed for the NCK program.

Recipes were adapted mainly to replace ultra-processed foods with unprocessed or minimally processed foods, following the recommendations of the GAPB [10]. The dietary guidelines of the United States, from which the CWC program was based on, neither discuss the degree of food processing nor recommend the elimination of trans fat, only its reduction [37]. The elimination of trans fat from the culinary recipes is in accordance with the recommendation of the World Health Organization (WHO) [27].

Added sugars were eliminated from some culinary recipes, such as fruit cream sherbet and salad dressings, as recommended by the WHO guidelines [29].

Recipes were also adapted by reducing the sodium content and increasing the amount of fresh herbs, seasonings, and spices without added sugars or salt. The WHO recommends that adults and children reduce their sodium intake [28] to reduce blood pressure and the risk of developing cardiovascular diseases. Studies revealed the benefits of using herbs, condiments, and spices such as cinnamon, ginger, and cumin for the treatment and prevention of diabetes and other associated complications [38,39].

Culinary recipes were modified by prioritizing one of the principles of the NCK program: to cook from scratch, using fresh or minimally processed ingredients [22]. Such adaptations are relevant, as the consumption of ultra-processed foods with excess trans-fat, sugar, and salt has been associated with weight gain, obesity, and the development of chronic non-communicable diseases [27,32-34].

In addition, we aimed at using seasonal vegetables, an important issue addressed by the United Nations Food and Agriculture Organization [40]. The culinary recipes developed for the NCK contain, preferably, organic ingredients from ecological agricultural systems. Organic production systems are used to produce healthy foods while protecting the environment and promoting the ecological use of natural resources [41]. The latest edition of the GAPB emphasizes that the consumption of organic foods stimulates agroecological family farms, respects traditional forms of production and knowledge, and promotes environmentally sustainable food systems [10].

Several adaptations were performed to respect the Brazilian food culture and ensure 
Table 1. Sensory score (\%) of the culinary dishes developed for the Nutrition and Culinary in the Kitchen cooking classes, evaluated by a panel of tasters. Santa Catarina (SC), Brazil, 2016.

\begin{tabular}{|c|c|c|c|c|c|c|}
\hline & \multirow{2}{*}{ Culinary dish } & \multicolumn{5}{|c|}{ Sensory score (\%) } \\
\hline & & Appearance & Color & Smell & Texture & Taste \\
\hline \multirow{6}{*}{ 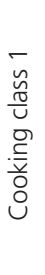 } & Roasted vegetables & 100 & 100 & 80 & 100 & 20 \\
\hline & Omelet & 60 & 80 & 100 & 80 & 60 \\
\hline & Fruit salad & 80 & 40 & 100 & 100 & 80 \\
\hline & Baked chicken & 100 & 100 & 100 & 80 & 80 \\
\hline & Poached chicken & 80 & 80 & 100 & 20 & 20 \\
\hline & Sautéed chicken & 100 & 100 & 100 & 100 & 20 \\
\hline \multirow{5}{*}{ 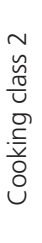 } & Chicken salad ${ }^{1}$ & 100 & 100 & 100 & 100 & 33 \\
\hline & Yogurt and mustard sauce ${ }^{1}$ & 100 & 100 & 100 & 100 & 33 \\
\hline & Fruit cream sherbet ${ }^{1}$ & 100 & 100 & 66 & 33 & 33 \\
\hline & Blender bread with seeds ${ }^{2}$ & 75 & 100 & 100 & 50 & 75 \\
\hline & Blender bread without seeds ${ }^{2}$ & 75 & 100 & 100 & 100 & 100 \\
\hline \multirow{6}{*}{ 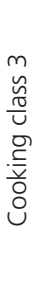 } & Black beans seasoned before cooking & 60 & 100 & 80 & 60 & 80 \\
\hline & Black beans seasoned after cooking & 100 & 80 & 100 & 100 & 100 \\
\hline & Beef steak with onions & 0 & 20 & 100 & 40 & 80 \\
\hline & Whole grain rice with garlic & 100 & 100 & 100 & 100 & 100 \\
\hline & Mixed salad & 60 & 80 & 100 & 100 & 100 \\
\hline & Vinaigrette dressing & 100 & 100 & 80 & 100 & 80 \\
\hline \multirow{6}{*}{ 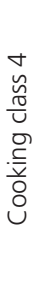 } & Roasted meatballs & 100 & 80 & 100 & 100 & 100 \\
\hline & Homemade tomato sauce & 60 & 20 & 100 & 100 & 80 \\
\hline & Whole wheat pasta & 100 & 100 & 100 & 100 & 100 \\
\hline & Broccoli salad with lentils & 100 & 100 & 100 & 100 & 100 \\
\hline & Balsamic vinegar salad dressing & 80 & 80 & 80 & 80 & 60 \\
\hline & Fresh fruit platter & 100 & 100 & 100 & 80 & 80 \\
\hline \multirow{7}{*}{ 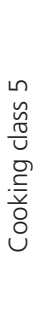 } & Fish stew with coconut milk & 100 & 80 & 100 & 80 & 100 \\
\hline & Parboiled rice with parsley & 100 & 100 & 100 & 100 & 100 \\
\hline & White bean salad & 100 & 100 & 100 & 80 & 100 \\
\hline & Orange, mustard, and honey salad dressing & 100 & 100 & 100 & 100 & 100 \\
\hline & Whole grain oatmeal and fruit cake & 100 & 100 & 100 & 100 & 100 \\
\hline & Farofa ${ }^{3}$ with butter & 100 & 100 & 100 & 80 & 40 \\
\hline & Fish pirão ${ }^{4}$ & 100 & 100 & 100 & 100 & 20 \\
\hline
\end{tabular}

Note: ${ }^{1}$ Evaluated by a panel of three tasters; ${ }^{2}$ Evaluated by a panel of four tasters; ${ }^{3}$ Traditional Brazilian dish made of cassava flour fried in butter or oil, which can be prepared with other ingredients (sausages, eggs, and vegetables); ${ }^{4}$ Traditional Brazilian dish made of cassava flour cooked in broth.

that the target audience identifies with the menu, which might stimulate participants to use the recipes in their daily lives. Uggioni et al. [42] emphasized that the preservation of traditional culinary recipes can be a means to maintain the identity of dishes. Therefore, we selected typical Brazilian dishes, such as fish, farofa, pirão, rice, and beans. The combination of rice and beans is a typical Brazilian dish and a source of carbohydrates, fibers, and proteins $[43,44]$. 
Chart 2. Culinary recipes that needed retesting, reasons and modifications, and final recipes. Santa Catarina (SC), Brazil, 2016.

\begin{tabular}{|c|c|c|}
\hline Culinary recipe & Reasons and modifications & Final culinary recipe \\
\hline Poached chicken & $\begin{array}{l}\text { The preparation method was altered to optimize the texture, } \\
\text { taste, and cooking time. }\end{array}$ & Pressure cooker chicken \\
\hline Sautéed chicken & The amount of salt was reduced by $42 \%$. & Sautéed chicken \\
\hline Omelet & $\begin{array}{l}\text { A larger frying pan was used, dry oregano was added, and } \\
\text { the amount of salt was reduced by } 50 \% \text {. }\end{array}$ & Omelet \\
\hline Fruit cream sherbet & $\begin{array}{l}\text { A larger amount of mango was added. The preparation } \\
\text { time was altered to enhance fruit flavor and maintain the } \\
\text { characteristic ice cream texture. }\end{array}$ & Fruit cream sherbet \\
\hline Blender bread & $\begin{array}{l}\text { The preparation method was altered to optimize the cooking } \\
\text { time. }\end{array}$ & Frying pan bread \\
\hline Cooked black beans & $\begin{array}{l}\text { Cooking time was reduced and the amount of water was } \\
\text { increased while maintaining the integrity of the beans and } \\
\text { pumpkin. }\end{array}$ & Cooked black beans \\
\hline Balsamic vinegar salad dressing & $\begin{array}{l}\text { Ingredients were altered to lower costs and enhance taste } \\
\text { attribute. }\end{array}$ & Lemon vinaigrette salad dressing \\
\hline
\end{tabular}

Food and Agriculture Organization determined 2016 as the "International Year of Pulses" to increase people's awareness of the nutritional benefits of beans and other legumes, the importance of their sustainable production, and their contribution to food security and nutrition [45].

Other recipes, such as frying pan bread and pressure cooker chicken, were chosen because of their practical preparation method. Difficulty in preparing culinary recipes, lack of time, yearn for financial savings, difficulty in making healthy food choices, and the dependence on convenience foods are referred to by young people as obstacles to cooking food at home [46-50]. Such obstacles can hamper the adoption of healthy food habits by university students $[46,47,51]$.

The target audience should be considered during the development of culinary recipes for intervention studies that focus on culinary skills. According to Tagnin \& Teixeira [52], an inadequate writing style may compromise the execution of a recipe. Therefore, it is important to test and evaluate culinary recipes before applying them in intervention programs to ensure that participants will benefit from the program.

A limitation of the present study was that we did not perform a triangle test with trained panelists for sensory evaluation [31]. However, an attempt to minimize this limitation was made by selecting people with experience in nutrition and inserted in the same environment as the target audience to evaluate the culinary recipes.

We highlight as a strength of this study the establishment of steps to develop culinary recipes that stimulate healthy eating, are adapted to NCK's target audience, and comply with Brazilian culture and reality. Culinary recipes were tested with university students that had experience in the area of nutrition and in food preparation techniques.

Another strength of this study is that recipes were developed and tested for the NCK program, which can be considered a pioneer program in Brazil. The NCK, to our knowledge, was the first intervention program aimed at developing culinary skills in Brazil. A study, which was the first randomized controlled study of a culinary intervention program with a six-month follow-up period reported in the literature, 


\begin{tabular}{|c|c|c|}
\hline \multicolumn{3}{|c|}{ Whole grain oatmeal and fruit cake } \\
\hline Preparation time: 15 min & Servings: 10 pieces & \\
\hline Cook time: 45 min & Serving size: 1 piece $(50 \mathrm{~g})$ & \\
\hline Ingredients & Household measure & Quantity (g or mL) \\
\hline Free-range egg & 3 units & $120 \mathrm{~g}$ \\
\hline Vegetable oil & $1 / 2$ cup & $120 \mathrm{~mL}$ \\
\hline Brown sugar & $3 / 4$ cup & $100 \mathrm{~g}$ \\
\hline Instant whole oatmeal & 2 cups & $200 \mathrm{~g}$ \\
\hline Prata banana & 4 small units & $153 \mathrm{~g}$ \\
\hline Fuji apple & 1 medium unit & $170 \mathrm{~g}$ \\
\hline Brazil nut & $1 / 2$ cup & $70 \mathrm{~g}$ \\
\hline Orange zest & 1 tablespoon & - \\
\hline Cinnamon powder (no added sugar) & 2 teaspoon & $5 g$ \\
\hline Baking powder & 1 tablespoon & $15 \mathrm{gl}$ \\
\hline \multicolumn{3}{|c|}{ Kitchen utensils and equipment } \\
\hline Cutting board & Fork & \\
\hline Vegetable knife & Teaspoon & \\
\hline Cup & Tablespoon & \\
\hline Grater & Bundt pan & \\
\hline Large bowl & Oven & \\
\hline \multicolumn{3}{|c|}{ Directions } \\
\hline \multicolumn{3}{|c|}{$\begin{array}{l}\text { 1. Wash and grate the apple. Add the cinnamon powder and mix well. Reserve. } \\
\text { 2. Wash, peel, and knead the bananas. Add to the grated apple. } \\
\text { 3. Preheat the oven for } 10 \text { minutes at } 220^{\circ} \mathrm{C} \text {. Chop the nuts. Zest the orange. } \\
\text { 4. In a bowl, add the oatmeal, sugar, eggs, and oil. Add the fruit mixture. Finally, add the nuts and baking powder. } \\
\text { 5. Grease and flour the pan. Pour in the cake mix. Bake for } 35-40 \text { minutes at } 220^{\circ} \mathrm{C} \text {. }\end{array}$} \\
\hline \multicolumn{3}{|c|}{$\begin{array}{l}\text { Tips: You can add other types of nuts and seeds such as cashew nuts, peanuts, and walnuts. You can also add dried fruits like raisins, } \\
\text { apricots, plums, and figs. This versatile recipe can be modified at any time. Use your creativity! }\end{array}$} \\
\hline
\end{tabular}

Figure 2. Example of a culinary recipe used in the cooking classes of the Nutrition and Culinary in the Kitchen program for Brazilian university students.

evaluated the program and its sustained effect. Nutrition and Culinary in the Kitchen cooking classes were first administered in 2016 for first- year students of a public university in southern Brazil [22]. The initial results of the intervention showed a positive impact on the development 
of culinary skills and healthier eating habits among the participants in comparison with the control group [53]. The culinary recipes, which were developed and tested as described in the present study, were applied in the first edition of the program [21].

We highlight a lack of scientific literature on the development of culinary recipes for intervention programs aimed at promoting culinary skills. The present study can fill this literature gap, as it presents the steps for the development of culinary recipes and a decision tree for the selection of recipes, tools that can be applied in future culinary intervention studies.

\section{CONCLUSION}

The methodological design elaborated in the present study for the selection, adaptation, development, and testing of culinary recipes can guide future interventions focusing on the development of culinary skills.

Culinary recipes adapted to the Brazilian food culture and the target audience with the use of healthy ingredients and cooking techniques were considered adequate for the NCK program and can increase participants' adherence to the program and healthy eating habits. It is important to test culinary recipes and evaluate their ease of comprehension for a successful culinary intervention.

We highlight that the process of developing and testing recipes described here was carried out in the context of the NCK program, a pioneer intervention program aimed at developing culinary skills. We expect that the first intervention promotes discussions on public health policies in the university setting. The NCK program can be adapted to similar audiences in other universities or to different audiences, as culinary interventions are important to promote healthy eating practices and the habit of cooking during all life stages and in all health conditions.

\section{CONTRIBUTORS}

HAK RITA contributed to the conception and design of the study; participated in the collection, analysis, and interpretation of data; and was responsible for writing and revising the manuscript. GL BERNARDO contributed to the conception and design of the study; data collection, analysis, and interpretation; and critical review of the manuscript. MM JOMORI, AC FERNANDES, and RPC PROENÇA contributed to the conception and design of the study, data analysis and interpretation, and critical review of the manuscript. All authors read and approved the final version of the manuscript.

\section{ACKNOWLEDGEMENTS}

The authors thank the Coordenação de Aperfeiçoamento de Pessoal de Nível Superior (Capes, Coordination for the Improvement of Higher Education Personnel, Brazil) for financing the data collection and granting a doctoral scholarship, to GL BERNARDO while they was in Brazil and during her internship carried out at Clemson University (6697/15-1), South Carolina, U.S. The study was also supported by the Human Resources Development Program (PRODEP, Programa de Desenvolvimento de Pessoal) at the Federal University of Alagoas (UFAL), Brazil for PhD scholarships granted to MM JOMORI and the Capes for scholarship during her internship carried out at City University London, London, UK. Furthermore, the study was supported by the National Council for Scientific and Technological Development (CNPq, Conselho Nacional de Desenvolvimento Científico e Tecnológico) by means Research Productivity Scholarship (303152/2015-0) granted to RPC PROENÇA.

\section{REFERENCES}

1. Nelson MC, Story M, Larson NI, Neumark-Sztainer D, Lytle LA. Emerging adulthood and college aged youth: An overlooked age for weight-related behavior change. Obesity. 2008;16(10):2205-11. http://dx.doi.org/10.1038/oby.2008.365

2. Levitsky DA, Halbmaier CA, Mrdjenovic G. The freshman weight gain: A model for the study of the epidemic of obesity. Inter J Obes. 
2004;28(11):1435-42. http://dx.doi.org/10.1038/ sj.ijo.0802776

3. Deliens T, Clarys P, Van Hecke L, Bourdeaudhuij I, Deforche B. Changes in weight and body composition during the first semester at university: A prospective explanatory study. Appetite. 2013;65:111-6. http://dx.doi.org/10.1016/j.appet. 2013.01.024

4. Lytle LA, Moe SG, Nanney MS, Laska MN, Linde $J A$, Petrich CA, et al. Designing a weight gain prevention trial for young adults: The CHOICES study. Am J Health Educ. 2014;45(2):67-75. http:// dx.doi.org/10.1080/19325037.2013.875962

5. Larson NI, Nelson MC, Neumark-Sztainer D, Story M, Hannan PJ. Making time for meals: Meal structure and associations with dietary intake in young adults. J Am Diet Assoc. 2009;109(1):72-90. http://dx.doi.org/10.1016/j.jada.2008.10.017

6. Zazpe I, Marqués M, Sánchez-Tainta A, RodríguezMourille A, Beunza J, Santiago S, et al. Hábitos alimentarios y actitudes hacia el cambio en alumnos y trabajadores universitarios españoles. Nutr Hosp. 2013;28(5):1673-80. http://dx.doi.org/10. 3305/nh.2013.28.5.6553

7. Maciel ES, Sonati JG, Modeneze DM, Vasconcelos JS, Vilarta R. Consumo alimentar, estado nutricional e nível de atividade física em comunidade universitária brasileira. Rev Nutr. 2012;25(6):707-18. http://dx.doi.org/10.1590/S1415-527320120006 00003

8. Bernardo GL, Jomori MM, Fernandes AC, Proença RPC. Food intake of university students. Rev Nutr. 2017;30(6):847-65. http://dx.doi.org/10.1590/16 78-98652017000600016

9. Ministério da Saúde (Brasil). Secretaria de Atenção à Saúde. Guia alimentar para a população brasileira: promovendo a alimentação saudável. Brasília: Ministério da Saúde; 2005 [acesso 2017 mar 24]. Disponível em: http://bvsms.saude.gov. br/bvs/publicacoes/guia_alimentar_populacao_ brasileira_2008.pdf

10. Ministério da Saúde (Brasil). Secretaria de Atenção à Saúde. Guia alimentar para a população brasileira: promovendo a alimentação saudável. 2a ed. Brasília: Ministério da Saúde; 2014 [acesso 2017 mar 24]. Disponível em: http://bvsms. saude.gov.br/bvs/publicacoes/guia_alimentar_ populacao_brasileira_2ed.pdf

11. Jomori MM, Vasconcelos FAG, Bernardo GL, Uggioni PL, Proença RPC. The concept of cooking skills: A review with contributions to the scientific debate. Rev Nutr. 2018;31(1):116-35. http://dx. doi.org/10.1590/1678-98652018000100010

12. Hartmann C, Dohle S, Siegrist M. Importance of cooking skills for balanced food choices. Appetite.
2013;65:125-31. http://dx.doi.org/10.1016/j.appet. 2013.01 .016

13. Thorpe MG, Kestin M, Riddell LJ, Keast RSJ, McNaughton SA. Diet quality in young adults and its association with food-related behaviours. Public Health Nutr. 2014;17(8):1767-75. http://dx. doi.org/10.1017/S1368980013001924

14. Reicks M, Trofholz AC, Stang JS, Laska MN. Impact of cooking and home food preparation interventions among adults: Outcomes and implications for future programs. J Nutr Educ Behav. 2014;46(4):259-76. http://dx.doi.org/10. 1016/j.jneb.2014.02.001

15. Warmin A, Sharp J, Condrasky MD. Cooking with a chef: A culinary nutrition program for college aged students. Top Clin Nutr. 2012;27(2):164-73.

16. Condrasky MD, Baruth M, Wilcox S, Carter C, Jordan JF. Cooks training for faith, activity, and nutrition project with AME churches in SC. J Eval Program Plann. 2013;37:43-9. http://dx.doi. org/10.1016\%2Fj.evalprogplan.2012.11.002

17. Kelly NR, Mazzeo SE, Bean MK. Systematic review of dietary interventions with college students: Directions for future research and practice. J Nutr Educ Behav. 2013;45(4):304-13. http://dx.doi. org/10.1016/j.jneb.2012.10.012

18. Stanley MK. Creating scrumptious and reliable recipes. Food Culinary Profs. 2015 [cited 2017 Jan 26]. Available from: http://www.foodculina ryprofs.org/docs/Newsletters\%20and\%20Inserts/ Summer\%202015.pdf

19. Hochman B, Nahas FX, Oliveira Filho RS, Ferreira, LM. Desenhos de pesquisa. Acta Cir Bras. 2005;20(Supl2):2-9. http://dx.doi.org/10.1590/S010 2-86502005000800002

20. Piovesan A, Temporini ER. Pesquisa exploratória: procedimento metodológico para o estudo de fatores humanos no campo da saúde pública. Rev Saúde Pública. 1995;29(4):318-25. http://dx.doi. org/10.1590/S0034-89101995000400010

21. Bernardo GL. Programa de intervenção sobre habilidades culinárias: adaptação, aplicação e avaliação do impacto nas práticas alimentares de estudantes universitários no Brasil [tese]. Florianópolis: Universidade Federal de Santa Catarina; 2017.

22. Bernardo GL, Jomori MM, Fernandes AC, Colussi CF, Condrasky MD, Proença RPC. Nutrition and culinary in the kitchen program: A randomized controlled intervention to promote cooking skills and healthy eating in university students: Study protocol. Nutr J. 2017;16(83):1-12. http://dx.doi. org/10.1186/s12937-017-0305-y 
23. Condrasky MD, Williams JE, Catalano PM, Griffin SF. Development of psychosocial scales for evaluation the impact of a culinary nutrition education program on cooking and healthful eating. J Nutr Educ Behav. 2011;43(6):511-6. http://dx.doi.org/10.1016/j.jneb.2010.09.013

24. Kerrison A, Condrasky MD, Sharp JL. Culinary nutrition education for undergraduate nutrition dietetics students. Br Food J. 2017;119(5):1045-51. http://dx.doi.org/10.1108/BFJ-09-2016-0437

25. Jomori MM, Proença RPC, Bernardo GL, Uggioni PL, Guanilo MEE, Fernandes AC. Construct validity of Brazilian cooking skills and healthy eating questionnaire by the known-groups method. Br Food J. 2017;119(5):1003-16. http://dx.doi. org/10.1108/BFJ-10-2016-0448

26. Ministério do Desenvolvimento Social e Combate à Fome (Brasil). Marco de referência de educação alimentar e nutricional para as políticas públicas. Brasília: Ministério do Desenvolvimento Social; 2012 [acesso 2017 mar 24]. Disponível em: http:// www.consed.org.br/media/download/54b65ffe 2730b.pdf

27. World Health Organization. Global strategy on diet physical activity and health. Geneva: WHO; 2004 [cited 2016 Nov 12]. Available from: http:// whqlibdoc.who.int/publications/2009/9789241 563888_eng.pdf

28. World Health Organization. Guideline: Sodium intake for adults and children. Geneva: WHO; 2012 [cited 2016 Nov 12]. Available from: http:// whqlibdoc.who.int/publications/2009/9789241 563888_eng.pdf

29. World Health Organization. Guideline: Sugars intake for adults and children. Geneva: WHO; 2015 [cited 2016 Nov 12]. Available from: http:// whqlibdoc.who.int/publications/2009/97892415 63888_eng.pdf

30. Núcleo de Estudos e Pesquisas em Alimentação. Tabela Brasileira de Composição de Alimentos - TACO. 4a ed. Campinas: Unicamp, 2011 [acesso 2018 jun 17]. Disponível em: http://www. nepa.unicamp.br/taco/contar/taco_4_edicao_ ampliada_e_revisada.pdf?arquivo=taco_4_versao_ ampliada_e_revisada.pdf

31. Domene SMA. Técnica dietética: teoria e aplicações. Rio de Janeiro: Guanabara Koogan; 2011.

32. World Health Organization. Diet, nutrition and the prevention of chronic diseases: Report of a Joint WHO/FAO expert consultation. Geneva: WHO; 2003 [cited 2016 Nov 12]. WHO Technical Report Series, No. 916. Available from: http://www.who. int/dietphysicalactivity/publications/trs916/en/
33. Canella DS, Levy RB, Martins APB, Claro RM, Moubarac J, Baraldi LG, et al. Ultra-processed food products and obesity in Brazilian households (2008-2009). Plos One. 2014;9(3):e92752. http:// dx.doi.org/10.1371/journal.pone.0092752

34. Bielemann RM, Motta JVS, Minten GC, Horta BL, Gigante DP. Consumo de alimentos ultraprocessados e impacto na dieta de adultos jovens. Rev Saúde Pública. 2015;49:1-10. http://dx.doi. org/10.1590/S0034-8910.2015049005572

35. Reis RC, Minim VPR. Testes de aceitação. In: Minim VPR, organizadora. Análise sensorial: estudos com consumidores. 3a ed. Viçosa (MG): EdUFV; 2013.

36. Souza LEP, Silva LMV, Hartz ZMA. Conferência de consenso sobre a imagem-objetivo da descentralização da atenção à saúde no Brasil. In: Hartz ZMA, Silva LMV, organizadores. Avaliação em saúde: dos modelos teóricos à prática na avaliação de programas e sistemas de saúde. Rio de Janeiro: Editora Fiocruz; 2005.

37. Departament of Health and Human Services (United States). Department of Agriculture. Dietary guidelines for Americans, 2015-2020. 8th ed. Washington (DC): US Department of Health and Human Services; 2015 [cited 2016 Nov 12]. Available from: https://health.gov/dieta ryguidelines/2015/resources/2015-2020_dietary_ guidelines.pdf

38. Bower A, Marquez S, Mejia EG. The health benefits of selected culinary herbs and spices found in the traditional mediterranean diet: Health benefits of culinary herbs and spices. Crit Rev Food Sci Nutr. 2016;56:2728-46. http://dx.doi.org/10.1080/104 08398.2013 .805713

39. Bi X, Lim J, Henry CJ. Spices in the management of diabetes mellitus. Food Chem. 2017;217:281-93. http://dx.doi.org/10.1016/j.foodchem.2016.08.111

40. Food and Agriculture Organization. Food climate research network at the University of Oxford. Oxford: FAO; 2016 [cited 2016 Nov 4]. Available from: http://www.fao.org/3/a-i5640e.pdf

41. Presidência da República (Brasil). Lei n 10.831, de 23 de dezembro de 2003. Dispõe sobre a agricultura orgânica e dá outras providências. Brasília: Diário Oficial da União; 2003 [acesso 2017 mar 24]. Disponível em: http://www.planalto.gov.br/ ccivil_03/leis/2003/L10.831.htm

42. Uggioni PL, Proença RPC, Zeni LAZR. Avaliação da qualidade de patrimônio gastronômico em restaurantes tradicionais. Rev Nutr. 2010;23(1):7-16. http://dx.doi.org/10.1590/S1415-527320100001 00002

43. Rodrigues AGM, Proença RPC, Calvo MCM, Fiates GMR. Perfil da escolha alimentar de arroz e 
feijão na alimentação fora de casa em restaurante de bufê por peso. Ciênc Saúde Coletiva. 2013;18(2):335-46. http://dx.doi.org/10.1590/S1 413-81232013000500005

44. Andrade GC, Costa Louzada ML, Azeredo CM, Ricardo CZ, Martins APB, Levy RB. Out-of-home Food consumers in Brazil: What do they eat? Nutrients. 2018;10(2):218.

45. Food and Agriculture Organization. International year of pulses. 2016 [cited 2018 Aug 14]. Available from: http://www.fao.org/pulses-2016/ about/en/

46. Larson NI, Perry CL, Story $\mathrm{M}$, NeumarkSztainer D. Food preparation by young adults is associated with better diet quality. J Am Diet Assoc. 2006;106(12):2001-7. http://dx.doi.org/10. 1016/j. jada.2006.09.008

47. Greaney ML, Less FD, White AA, Dayton SF, Riebe $D$, Blissmer $B$, et al. College students' barriers and enablers for healthful weight management: A qualitative study. J Nutr Educ Behav. 2009;41(4):281-6. http://dx.doi.org/10.1016/j.jneb. 2008.04.354

48. Lavelle F, McGowan L, Spence M, Caraher M, Raats MM, Hollywood L, et al. Barriers and facilitators to cooking from 'scratch' using basic or raw ingredients: A qualitative interview study. Appetite. 2016;107:383-91. http://dx.doi. org/10.10 16/j.appet.2016.08.115

49. Wolfson JA, Bleich SN, Smith KC, Frattaroli S. What does cooking mean to you? Perceptions of cooking and factors related to cooking behavior. Appetite. 2016;97:146-54. http://dx.doi.org/10.10 16/j.appet.2015.11.030

50. Murray DW, Mehadevan M, Gatto K, O'Connor K, Fissinger A, Bailey $D$, et al. Culinary efficacy: An exploratory study of skills, confidence, and healthy cooking competencies among university students. Perspect Public Health. 2016;136(3):143-51. http:// dx.doi.org/10.1177/1757913915600195

51. Deliens T, Clarys P, Bourdeaudhuij I, Deforche B. Determinants of eating behaviour in university students: A qualitative study using focus group discussions. BMC Public Health. 2014;14(1):1. http:// dx.doi.org/10.1186/1471-2458-14-53

52. Tagnin SEO, Teixeira ED. Lingüística de corpus e tradução técnica-relato da montagem de um corpus multivarietal de culinária. Tradterm. 2004;10:313-58. http://dx.doi.org/10.11606/issn. 2317-9511.tradterm.2004.47184

53. Bernardo GL, Jomori MM, Fernandes AC, Condrasky M, Colussi CF, Proença RPC. Positive impact of a cooking skills intervention among Brazilian university students: Six months follow-up of a randomized controlled trial. Appetite. 2018; 130:247-55. http://dx.doi.org/10.1016/j.appet.2018. 08.014
Received: February 2, 2018

Final version: June 25, 2018 Approved: August 2, 2018 